\title{
The MARKETNET Concept of Regional Sustainable Development Strategy
}

\author{
Aleksander Kovalev ${ }^{1}$, Natalya Rebrova $^{1}$, and Margarita Zhidkova, ${ }^{2, *}$ \\ ${ }^{1}$ Financial University under the Government of the Russian Federation, Omsk Branch, 644099 \\ Partizanskaya st. 6, Omsk, Russia \\ ${ }^{2}$ Moscow Automobile and Road Construction State Technical University (MADI), 125319 \\ Leningradsky prospect 64, Moscow, Russia
}

\begin{abstract}
At the present stage, there is an objective need for the competent use of strategic planning tools at the regional level. The authors analyze the strategy of regional development by the example of Omsk, Rostov, Yekaterinburg and other regions and St. Petersburg. They show the supporting role of marketing in the strategic planning of the regions and the priorities of TICK strategy. The authors highlight the interrelation between the development of mining sector and the development of social programs and tourism in the Eastern Donbas. They conclude that it is necessary to develop marketing strategies and implement the MARKETNET regional concept in the Omsk region and distribute it in other regions of the country.
\end{abstract}

\section{Introduction}

Researchers note that more and more territories resort to strategic market planning, in contrast to those that are engaged in planning one-off events. However, in our opinion, before starting to develop strategic programs and plans, it is necessary to analyze the interests of the region, possible development scenarios, main barriers and opportunities. In addition, the main target groups of the region, such as the population, investors, tourists, businessmen, should decide what region they want to see in 5-10 years, and what social-and-economic niches it needs to occupy in the face of growing competition. All of these key questions can be answered by strategic regional planning, which is actively used by many Russian regions.

At the same time, the development strategy of the region is the ground for marketing; it points out the main directions and sets tasks that must be constantly adjusted depending on the results achieved. In this sense, it is much easier to plan a marketing program for achieving strategic indicators for a region that has a clear development strategy. Thus, promotion of the interests of the region and its development through marketing tools becomes meaningful and purposeful.

\section{Materials and Methods}

Drawing parallels between marketing and strategic planning, it is worth bearing in mind that

\footnotetext{
*Corresponding author: info@madi.ru
} 
strategic planning answers the question: which region needs to be developed and promoted to achieve what goals. And marketing defines how these goals can be achieved, i.e. how to promote and to develop the region. Accordingly, we can conclude that marketing is a key component of strategic regional planning in terms of implementing the benchmarks laid in it.

This is another great plus of using marketing technologies: marketing activities stimulate the development of strategies for the development of regions [1]. The supporting role of marketing in strategic planning of regions is the following (Figure 1).

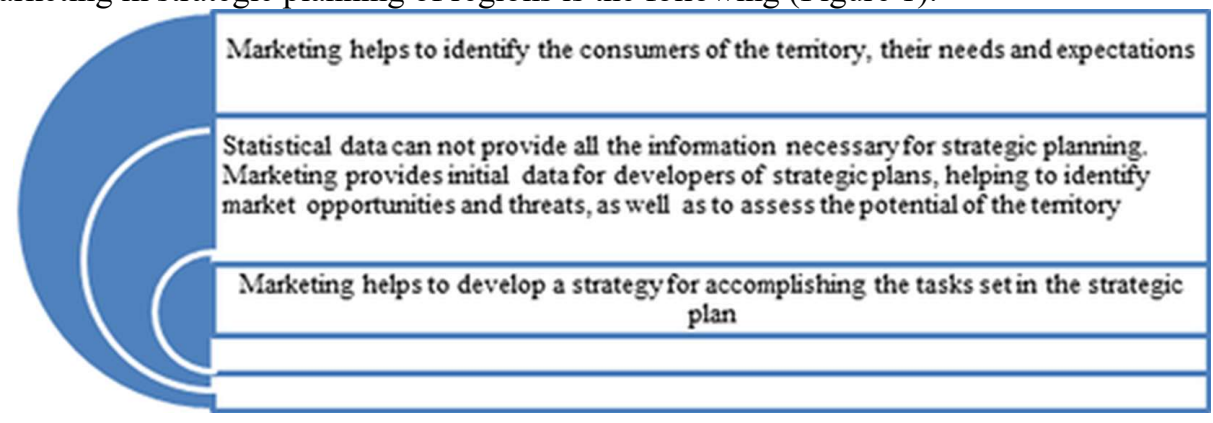

Fig. 1 The role of marketing in strategic planning of regions.

There is a fairly large number of classifications of marketing strategies applied at the regional level. Our own theoretical and practical studies have allowed us to form our own classification of strategies, which has been used for several years to solve the problems of territorial development of the Omsk region - one of the largest territorial entities in Russia. This classification of marketing strategies is called TICK, where:

- T (Tourism) - strategy of attracting tourists;

- I (Investment) - strategy of attracting investments;

- $\mathrm{C}$ (Comfort) - strategy of providing comfort for the inhabitants of the region;

- K (Know-how) - strategy of creativity in the development of image aspects.

It is easy to see that this approach allows focusing on really priority basic tasks of marketing the territory and removing those procedures and operations that at a certain stage may to some extent "interfere" with the strategic vision.

\section{Results and Discussion}

In our given strategic decisions in the Omsk region, specific directions of the region's development are identified and implemented, allowing it to integrate effectively into the Russian system of social-and-political and economic relations.

So, within the framework of the $\mathrm{T}$ strategy, there are such priorities as the development of a tourist center in the Omsk region; development of the system of intra-regional tourism, improving the organization of events with an excellent reputation, and a recognizable brand: "Siberian International Marathon" (SIM).

Strategy I, aimed at increasing the investment and financial attractiveness of the region, defines the following key areas:

- conducting competent cluster policy in the region;

- developing the necessary infrastructure;

- developing the heat and power engineering;

- developing the construction industry and real estate market in the region;

- creating a favorable environment for the development of small and medium-sized businesses;

- developing telecommunication service.

It should be mentioned that the cluster policy is not accidentally leading this list. Studies 
made by Omsk specialists showed that the organizational and managerial resources manifested in the formation of clusters have the most "tangible" potential for the development of the region.

Strategy $\mathrm{C}$ assumes a real improvement in the quality of life. So in the Omsk region it was possible to clearly define the priorities for the development of the region for 2015-2025 basing on this strategy. They are:

- improving the quality and accessibility of medical services;

- improving the quality of access to educational services, especially in the field of secondary vocational education;

- reengineering of housing and communal services in the region;

- targeted social insurance of the population;

- ecology;

- changing the mentality of different population groups in relation to physical culture and sports.

Strategy $\mathrm{K}$ assumes the creation of a creativity managing system in the sphere of advertising; PR; brand management - in the sphere where a positive image of the region is formed in the domestic and international markets [1-3]. The presented priorities of these strategies are summarized in Table 1.

Table 1. The priorities of TICK strategy by the example of the Omsk region.

\begin{tabular}{|c|c|c|c|}
\hline \multicolumn{4}{|c|}{ The priorities of TICK strategy } \\
\hline $\mathbf{T}$ & I & $\mathbf{C}$ & $\mathbf{K}$ \\
\hline $\begin{array}{l}\text { the development } \\
\text { of tourist center in } \\
\text { the Omsk region }\end{array}$ & $\begin{array}{l}\text { the implementation of } \\
\text { competent cluster policy } \\
\text { in the region }\end{array}$ & $\begin{array}{l}\text { improving the quality } \\
\text { and accessibility of } \\
\text { health services }\end{array}$ & $\begin{array}{l}\text { creation of a system for } \\
\text { managing creativity in } \\
\text { advertising }\end{array}$ \\
\hline $\begin{array}{l}\text { the development } \\
\text { of intra-regional } \\
\text { tourism system }\end{array}$ & $\begin{array}{l}\text { the development of } \\
\text { necessary infrastructure }\end{array}$ & $\begin{array}{l}\text { improving the quality } \\
\text { of access to } \\
\text { educational services, } \\
\text { especially } \\
\text { secondary vocational } \\
\text { education }\end{array}$ & PR development \\
\hline \multirow{4}{*}{$\begin{array}{l}\text { improving the } \\
\text { organization of } \\
\text { events with an } \\
\text { excellent } \\
\text { reputation, and a } \\
\text { recognizable } \\
\text { brand: "Siberian } \\
\text { International } \\
\text { Marathon" (SIM) }\end{array}$} & $\begin{array}{l}\text { the development of heat } \\
\text { and electricity }\end{array}$ & $\begin{array}{l}\text { reengineering of } \\
\text { housing and } \\
\text { communal services of } \\
\text { the region }\end{array}$ & $\begin{array}{l}\text { brand management - } \\
\text { that is, creating a } \\
\text { positive image of the } \\
\text { region on the domestic } \\
\text { and international } \\
\text { markets. }\end{array}$ \\
\hline & $\begin{array}{l}\text { the development of } \\
\text { construction industry } \\
\text { and real estate market in } \\
\text { the region }\end{array}$ & $\begin{array}{l}\text { targeted social } \\
\text { insurance of the } \\
\text { population }\end{array}$ & \\
\hline & $\begin{array}{l}\text { the creation of a } \\
\text { favorable environment } \\
\text { for the development of } \\
\text { small and medium } \\
\text { business }\end{array}$ & ecology & \\
\hline & $\begin{array}{l}\text { developing } \\
\text { telecommunication } \\
\text { service }\end{array}$ & $\begin{array}{l}\text { the change in } \\
\text { mentality of different } \\
\text { population groups in } \\
\text { relation to physical } \\
\text { culture and sports }\end{array}$ & \\
\hline
\end{tabular}

It is worth mentioning that our own observations and the opinions of different respondent groups revealed in the course of regular monitoring conducted by specialists of Omsk 
universities allow perceiving the local creativity factor as a potential, the degree of implementation of which is extremely low unlike such "creative" regions as Yekaterinburg and Tyumen.

Adequate classification and a clear format of marketing strategies represent a stepping stone in activities related to the strategic development of the region [4-6]. However, whatever classification is used in practice, achieving the strategic objectives of the region often slows down, requires a significant overrun of the planned set of resources [7-8]. It can be argued that the key problem of this phenomenon is the organizational disparity of marketing strategies [9-10]. They are implemented by various structures of the region; on the basis of unconnected information bases and conflicting operational priorities and targets. So, as a result of uncoordinated actions, one of the most important strategies of the Omsk region the logistic, connected with the development of the air and underground transport system, was torn from the context of the General Development of the region, and its implementation is postponed on indefinite time.

The authors believe that in order to combine all forms of marketing activity in the region, a so-called "synergetic approach" is necessary and sufficient to achieve the agreed marketing strategies defined by the region. In this regard, the regional concept of "MARKETNET" is assumed. Like the Internet, "MARKETNET" integrates all the marketing efforts that are being implemented on the territory; a unified intellectual, information and financial base will be created for coordinated implementation of the developed marketing strategies, which is no less important for effective control over their implementation.

The term "MARKETNET" was "launched" in the educational process of the universities of Omsk by the authors and received positive assessments.

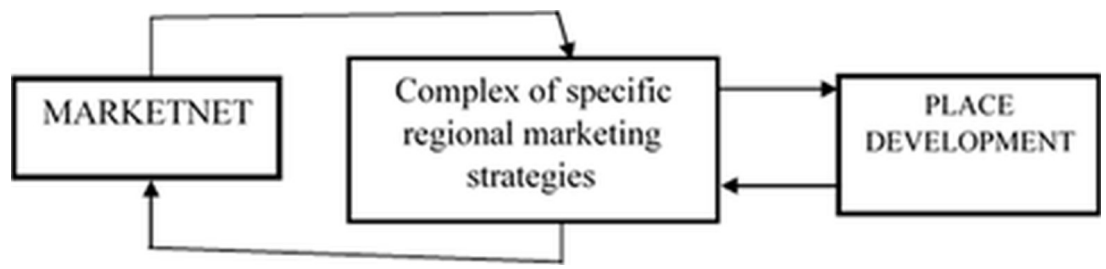

Fig. 2. CHART I Place market net - «MARKETNET» concept.

The "MARKETNET" concept seems to be relevant and fits into the ideology and policy of the digital economy.

The implementation of the integrated "MARKETNET" concept in the region assumes the availability of an adequate information base and carefully selected tools. In order to make the region really famous - FAME - the architecture of the tools for strategic (and operational) marketing activities should be built according to the FAME principle (of course, certain variations are allowed).

$\mathrm{F}$ - financial tools (FINANCE);

A - tools for studying attractiveness (ATTRACTION);

$\mathrm{M}$ - tools for studying mentality (MENTALITY);

$\mathrm{E}$ - tools for studying the environment (ENVIRONMENT).

As an example of comprehensive and effective use of tools within the framework of this classification, the activities of professional and public organizations of St. Petersburg in the development of attractiveness of the territory can be described. The northern capital St. Petersburg has truly inexhaustible resources of attractiveness. They do not work by themselves; their constant monitoring and the use of effective methods and methods of their study allow getting finally the desired result - a systematic increase in the attractiveness of the city. St. Petersburg is very popular not only among domestic, but also foreign tourists. 
The center of this city is on the UNESCO World Population List. There is an extremely high concentration of museum, historical and cultural spectacle objects (the Hermitage, the Russian Museum, the Bolshoi Drama Theater, the Opera and Ballet Theater, the park complex of Peterhof, Pavlovsk, Gatchina, etc.) in the city and its suburbs.

The growth of attractiveness of St. Petersburg is provided by such funds, which are in the field of view of marketers, as globalization, improvement, quality of tourism and other services, their greater accessibility, development of tourist infrastructure, improvement of the tourist security system, simplification of visa procedures, the formation of new tourist routes, the emergence of firm-discounters, which will lead to increased competition in the air carrier market and, consequently, to a decrease in the cost of air tickets.

However, in addition to the attractiveness of the city for tourists, it can be of interest to people wishing to get affordable, variable education of a high quality (in leading universities of St. Petersburg in key indicators, the level of education is higher than the average Russian level). In the list of the top 100 Russian universities in 2016 among the first forty there are St. Petersburg State University, St. Petersburg Political University of Peter the Great, St. Petersburg National Research University of Information Technologies, Mechanics and Optics, the first St. Petersburg Medical University named after Academician I. P. Pavlov, St. Petersburg Electro-technical University "LETI" named after V. Ulyanov.

The presence of large and well-known higher educational institutions, as well as good conditions for the self-realization of graduates (low level of youth unemployment) and a worldwide trend towards an increase in population mobility could help transforming St. Petersburg into a major international educational center.

The development and implementation of industrial projects, as well as the development of tourism, attracts foreign investors to the Russian regions. This should contribute not only to the growth of industry in the regions in the long term, but also to the development of social and tourist sphere.

For example, in Rostov region coal has been mined for three centuries, but in the $1990 \mathrm{~s}$ the number of mines in the Eastern Donbas decreased from 64 to 13. Coal production fell sharply, having led to unemployment and population migration to more prosperous regions of the country, such as Moscow, St. Petersburg, etc. However, recently the coal industry began to recover: in May 2017 in the territory of mine "Sadkinskaya" a group concentrator factory started operating. In 2018, it is planned to produce 2 million tons of anthracite, which will be processed in a new factory. At present, "Sadkinskaya-Severnaya" mine is being designed, and "Sadkinskaya-Vostochnaya" mine is under construction.

It is expected that in 2-3 years, when both mines start operating, the enterprise will be able to extract as much anthracite as the entire East Donbass extracts. Deep processing of raw materials will allow obtaining high-tech products that are in demand in the world market. This opinion is shared by Shpilkina T.A., who notes that "... the majority of high-tech Russian companies (which, unfortunately, are not so numerous) have good prospects of bringing their products to the foreign market ..." [7].

\section{Conclusion}

The opening prospects for the development of the Rostov region will provide an opportunity to attract young people and middle-aged people interested in living and working in the region. But for this it is necessary not to forget about the development of social programs for all population groups.

It is planned to create interesting tours in the region, both for Russian and foreign tourists, and bonus programs during visiting museums, theaters and historical places, as well as creating sports grounds. The results of implementing the development strategy of regions and tourist flows can be assessed already in the autumn after FIFA World Cup is held. This 
event will reveal both positive and negative factors, so that in future there will be an opportunity to focus on the most interesting social and tourist programs, take into account the mistakes which will increase the attractiveness of the regions.

\section{References}

1. S.A. Zhironkin, Ugol', 4, 47-49 (2002)

2. S.A. Zhironkin, , Ugol', 6, 62-63 (2001)

3. E. Dotsenko, E3S Web Conf., 21, 04013 (2017)

4. E. Dotsenko, N. Ezdina, A. Prilepskaya, K. Pivnyk, E3S Web Conf., 21, 04014 (2017)

5. E.A. Gasanov, M.A. Gasanov, Economics and Innovation Management, 1, 30-38 (2017) DOI: 10.26730/2587-5574-2017-1-30-38

6. M. Prokudina, O. Zhironkina, O. Kalinina, M. Gasanov, F. Agafonov, E3S Web Conf., 21, 04003 (2017)

7. V. Frolova, O. Dolina, T. Shpil'kina, E3S Web Conf., 21, 04018 (2017)

8. E. Dotsenko, E3S Web of Conf., 21, 04013 (2017)

9. E. Shavina, O. Kalenov, E3S Web of Conf., 21, 04025 (2017)

10. A. Balabanova, V. Balabanov, E. Dotsenko, N. Ezdina, E3S Web of Conf., 15, 04013 (2017) 